Poznańskie Studia Teologiczne 30(2016), s. 121-140.

doi: $10.14746 /$ pst.2016.30.05

\author{
Piotr Nawrot ${ }^{1}$ \\ Uniwersytet im. Adama Mickiewicza w Poznaniu \\ Wydział Teologiczny
}

\title{
Indian Music to Celebrate Christmas in Moxo Jesuit Reductions, Bolivia
}

The subject of Indian music from the former Jesuit Reductions in South America needs new studies, and what has been said on this matter up to now by musicologists and ethnomusicologists needs revision. Until recently, the first group of scholars based their theories mostly on narratives provided by the missionaries and some visitors of the mission villages (religious or secular), while the second group was concerned mainly with oral tradition that preserved music until our time.

Even though new music of European precedency - mainly Renaissance and Baroque - was applied in evangelization of the Indian tribes in America, native music was very present and durable in the life of the Indian communities. With the passing of time and as a result of the living together of missionaries and new converts to Catholicism, European music gradually influenced autochthonic melodies, rhythms and harmonies, and vice versa, local songs and airs, pulses, instruments and languages were applied to what was considered properly European. The foundation of missions among American communities did not necessarily mean discrimination or elimination of local musical culture.

A Jesuit missionary among Moxo Indians, Francisco Javier Eder, in his Breve descripción de las reducciones de Moxos, left us an exceptional description of Indian music and dance applied in celebrations of Christian festivities. Eder speaks not only of one ethnic group - a given mission village was generally populated by different indigenous tribes - but several of them.

Eder:

Usually each ethnic group does not mix with the other, dancing each in separate groups.... Adorn the head with feathers, forming crowns, circles or other shapes, as

\footnotetext{
${ }^{1}$ Piotr Nawrot. Professor at WT UAM and artistic director of the Baroque Music Festival, „Misiones de Chiquitos" in Bolivia. His researched focused on musical manuscripts from the former Jesuit Reductions in South America. He published over 40 volumes of music from the Chiquitos, from the Moxos and from the La Plata (today Sucre) Cathedral sources of historic music in Bolivia.
} 
complicated as elegant. I confess that it constitutes a spectacle worthy of all praise... here and there scattered groups of Indians, whose heads with so many different plumes... What [painter's] brush can ever imitate those colors? In the legs, below the calves, tied a kind of almonds.... Its fruit, separated from the shell, is hard, so when you shake it, it sounds noisier than if you tied hazelnuts, so that you can call them bells...

$[\ldots]$

But the remaining Indians, exclusively dancers, are divided in two equal rows and face each other, playing their flutes and dancing at the same time.... The footwork is such that each hand movement corresponds to each footstep.... When dancing, they lean a little with their heads, uniting them fully [one with the other].... With their feet, more than touching, [the dancers] shake the ground, so that the bells produce more noise. Each time when the second bass [instrument] intervenes, those who have attached to their bodies the mentioned laden cord, full of shells and other fancies, shake their backs with all possible force.... This dance often lasts half an hour...

Regarding instruments that accompanied the dancers:

Their instruments are canes that they themselves cut so that the longest is barely an inch long; one beyond the other in a whole tone scale.... Sometimes making these flutes is done so precisely, that even the wisest musician cannot find the slightest dissonance.... Cut the canes so they can play two lines of notes: one for one, the tie with two rods, as a body; on the opposite side, which should serve to the other note. Each wears around his neck this dual instrument....

Their music does not lack a bass line, for they have two types of instruments: the first is made of long - some other round - pumpkins planted exclusively for this use. Blowing long as we trumpets; to round put a reed through which make them sound. Others, instead of using pumpkins (which often does not leave them to grow to reach its full growths or, if grown, insects devour them), build their elegant flutes with palm leaves. All of them add a large drum, which the Indian hits with one stick, under the laws of rhythm. All dances coincide in the same tempo $2 \times 4$, whose double time (that musicians often point hand) so mark the drum with his stick and dancers, feet. ${ }^{2}$

\section{Place of Indian Music in the Music Repertoire from the Missions}

Is there any native Indian music from the time of the Spanish Colony in America that can be found in multiple music archives spread from north to south in the New World? Not much. There is no evidence that music in America prior to the arrival of Columbus was codified into a musical system. Native American music was, mainly, transmitted orally. No one denies, however, that at least in some major American nations, musical culture was quite advanced. Thus, when

${ }^{2}$ F.J. Eder, Breve Descripción de las Reducciones de Mojos, tr. and ed. J.M. Barnadas, Historia Boliviana, Cochabamba 1985, pp. 287-288. 
the native musicians met European music, within a short time they were able to learn and appreciate it, and find delight in performing it. Scholars are divided in attributing Spanish colonial music in America to Indian-blood composers. Some deny any evidence that an Indian musician would have the capacity of expressing himself through new music, while others see the opposite. Already, colonial sources that narrate on music from Spanish America add to this controversy. For example, Juan de Torquemada, a historian and Franciscan missionary in Mexico, in his Monarquía Indiana (1615), commenting on musical activities in Mexico left the following testimony with regard to Indian-blood composers in his time:

With this I conclude (and this is an important observation): only a few years after the Indians began to learn the chant, they also began to compose. Their villancicos, their polyphonic music in four parts, certain masses and other liturgical works, all composed with adroitness, have been considered superior works of art when shown Spanish masters of composition. Indeed the Spanish masters often thought they could not have been written by Indians. ${ }^{3}$

If Torquemada is right - and I strongly believe he is - the Indian-blood musicians should not be seen only as performers and imitators of European music language, but also as creative musicians with the full capacity of composing new, to them, music. In a similar way, while performing music from Europe or already from America, local artists would introduce in their execution stylistic originalities proper to their preferences for sound, possibilities, and occasion.

The most striking Indian influence on the $17^{\text {th }}$ century motet in America is the use of texts in Indian languages. Recently, some of these compositions, particularly in Nahuatl, Quechua, and Chiquito languages, gained their way to be among the most popular compositions chosen by choirs and ensembles specializing in interpretation of historic music in America, Europe and Asia. Thus, before moving to Moxo mission territory, let us approach this matter in Spanish cathedrals, first in Puebla, than in Cuzco.

In the $17^{\text {th }}$ century Mexico, a local organist of the Puebla cathedral, Gaspar Fernandes (1566-1629) ${ }^{4}$, composed a short motet, Xicochi conetzintle, to solemnize Christmas celebration. Although his music has the typical format of $17^{\text {th }}$ century motet popular in the New World (chanzoneta a 4), the use of the local Nahuatl language gives this composition a prominent place in the repertoire of Spanish colonial music in America. Even though this chanzoneta has several

\footnotetext{
${ }^{3}$ Quoted after: R. Stephenson, Music in Aztec \& Inca Territory, Berkeley-Los Angeles 1968, p. 172. In: J. de Torquemada, Tercera parte de los veinte $i$ un libros rituales (1723), p. 214, [Bk. XVII, chap. 3]. See also: J. de Torquemada, Monarquía Indiana. De los veinte y un libros rituales y monarquía indiana, con el origen y guerras de los indios occidentales, de sus poblazones, descubrimiento, conquista, conversión y otras cosas maravillosas de la mesma tierra, México 1975.

${ }^{4}$ Composer from Portugal, active in Guatemala and Mexico (Santiago de Guatemala and Puebla de los Ángeles), sometimes referred to as Gaspar Fernández.
} 
editions $\mathrm{s}^{5}$, to help in grasping and visualizing the differences between music from the cathedrals in America and from the missions, we offer here a transcription of this motet based on what was accessible on the Internet.

\author{
Xicochi, xicochi, \\ Xicochi, xicochi \\ Xicochi conetzintle \\ Xicochi conetzintle \\ Caomiz hui hui xoco in anqelos me \\ Caomiz hui hui joco in anqelos me \\ Caomiz hui hui joco in anqelos me \\ In anqelos me in anqelos me. \\ Alleloya. Alleloya.
}

Sleep, sleep

Sleep, sleep

Sleep, O my child

Sleep, O my child

Indeed, the angels have come to call you (into the world)

Indeed, the angels have come to call you (into the world)

Indeed, the angels have come to call you (into the world)

Alleluia, alleluia. ${ }^{6}$

European polyphony was popular among Indian musicians everywhere the Spanish church founded its cathedrals, parishes, and convents. Even though most of them hired Spaniard - sometimes Portuguese or Italian - musicians as maestro de capilla, artists that sung in the choir and played in orchestra were predominantly Indians, who were well educated and supervised in the local music schools. Thus, it must have been easy for them to sing villancicos, motets or simple songs in native verses that, probably, were sung with more energy and delight than Spanish or Latin texts. ${ }^{7}$ The repertoire of Renaissance or Baroque

\footnotetext{
${ }^{5}$ Among others: Drew Edward Davies, Aurelio Tello, Omar Morales others.

${ }^{6}$ See: en.wikipedia.org/wiki/Xicochi. Also: T.D. Watkins, Finding Nahua Influence in Spanish Colonial Music, Rhodes College. Hassell Hall. 24 Sept. 2008.

Transcription of text in Nahuatl follows orthography and criteria for transcription applied by Omar Morales.

${ }^{7}$ After thirty-three years of missionary and scholarly work in Latin America, and preparing a music festival in Bolivia (International Festival of Renaissance and Baroque Music in America, "Misiones de Chiquitos"), I had a chance to prepare three programs of baroque music from the Bolivian archives with texts in local languages: Guarani, Chiquitano, Guarayo. This music was to be interpreted by native singers and players representing each one of these groups. All of them had some formation in the field of so-called academic music, since in each of those villages of the lower parts of Bolivia, there is a music school founded; a music school that follows the model of mu-
} 


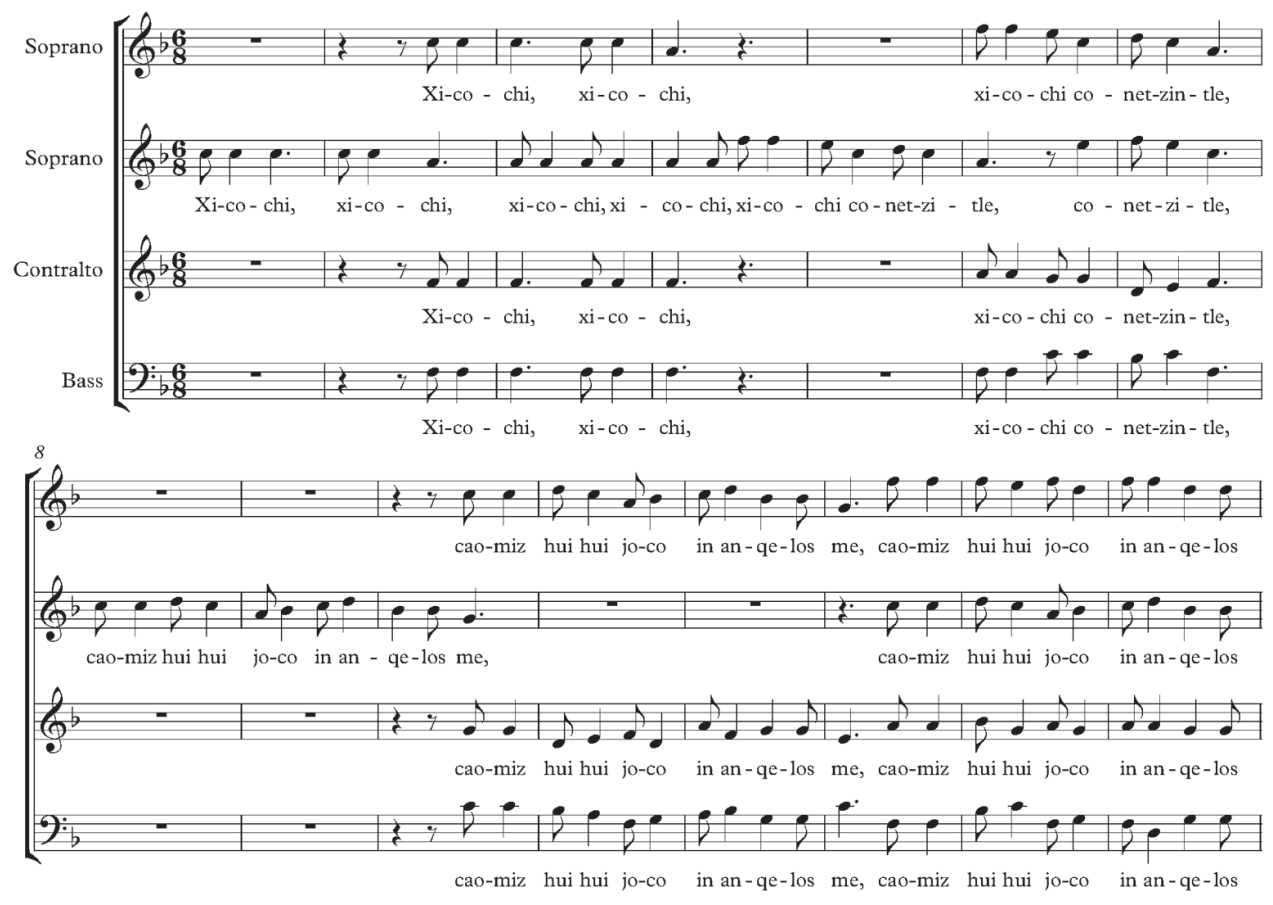

Music example 1: Chicochi

music with lyrics in American tongues is not very broad when compared to Latin or Spanish verse, but could be located in many places where music from the Colonial times still exists. Moving from Mexico closer to Moxos, the music collection from the Cuzco cathedral keeps another jewel of that sort: Hanacpachap cussicuinin - a four-part song with text in imperial Quechua language that was included in Juan Pérez Bocanegra's Ritual of 1631, which on its part, is the first vocal polyphonic music printed in the New World. ${ }^{8}$ Professor Robert Stephenson was the first one to call our attention to its existence and offered the first transcription of it. Here is its new edition that follows Stephenson's model.

sic school in the former Jesuit or Franciscan reductions. Up to that moment, they mostly performed Latin polyphonic masses, lamentations, litanies etc., or Spanish motets or villancicos (they do not speak Latin, and they learn Spanish when they reach school age). However, when they have been given - for the first time in modern history - historic music from their own archives with text in their own tongue, they learnt it much faster and performed these compositions with such energy that the audience unanimously acclaimed that they never had heard these ensembles singing this repertoire with such enthusiasm, energy and pride.

${ }^{8}$ R. Stephenson, Music in Aztec \& Inca Territory, op. cit., p. 280. 

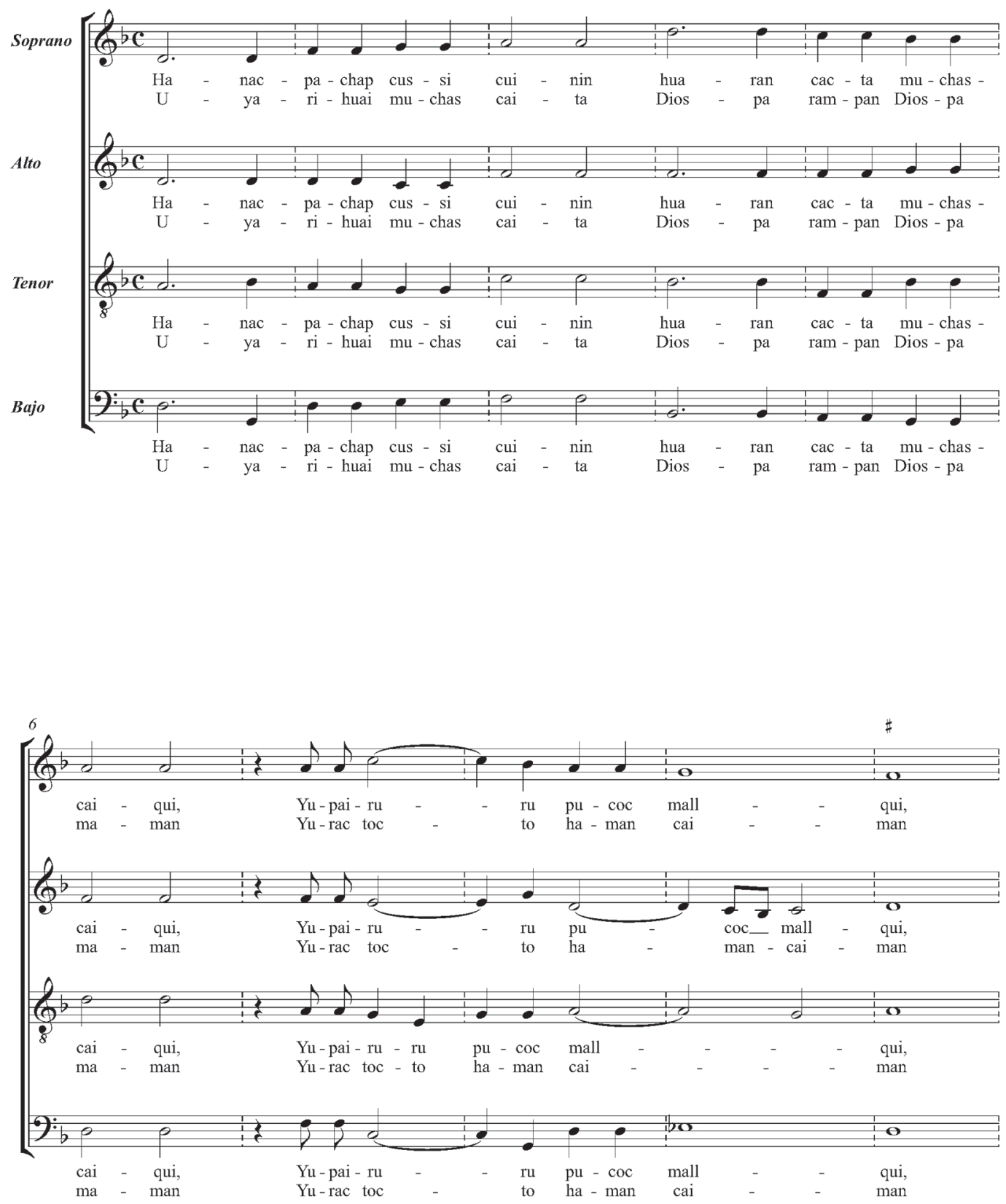


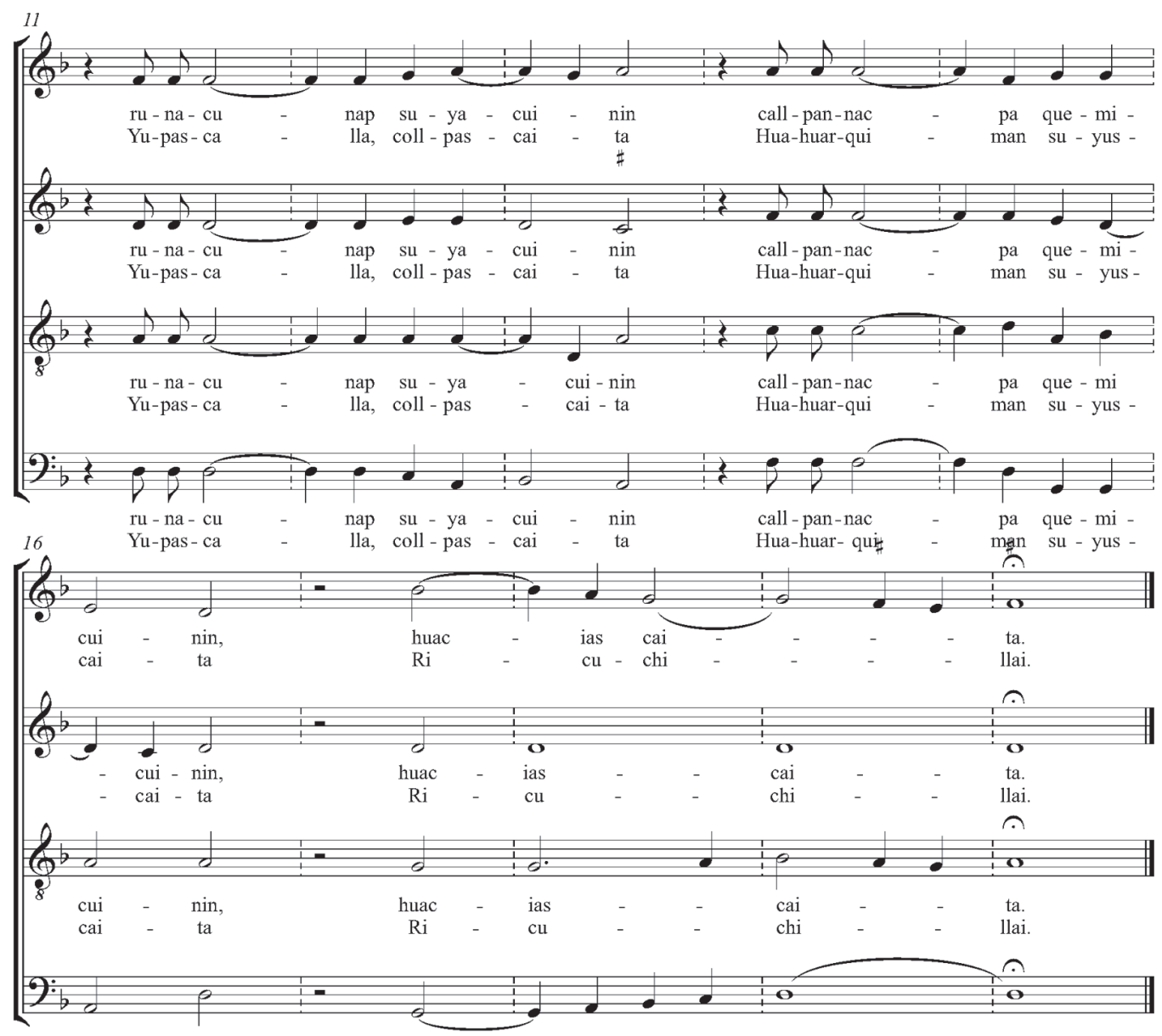

Music example 2: Hanacpachap

Studies have shown that during the first centuries of Spanish colonization of America, authors of lyrics in Indian languages, or translators of foreign texts converted in American tongues, when referring to religious names or concepts, kept the original Spanish or Latin expression. Thus, it is common that in vocal music from Colonial America in Indian tongues there is a mix of local and foreign, like for example, the second verse of the Apostles' Creed translated into Quechua, Capac eterno Dios (Almighty and eternal God):

Cam Sancta Trinidad: Dios yaya: Dios churi: Spiritu Sancto Dios... 9

${ }^{9}$ R. Stephenson, p. 279. 
Such practice can be seen in almost every composition of this sort from Colonial America, but even more so with music from the mission territories, where the repertoire of music with texts in local tongues is considerably broader than the collection of music with texts in Spanish. In the Chiquito collection of music a mix of local and foreign can be seen very often, as for example: Caîma, Iyâे Jesus; Zuipaquî, Santa Maria; Anaustia Santissimo Sacramento and many other compositions. In addition, in the same collection, in some cases, a new practice developed, alternating verses, first in Spanish, than in Chiquitano language was implemented, as it is attested in Dulce Jesús mío (Yyaî Jesuchristo, apoquîrui).$^{10}$ Moving to Moxo missions, the same trend can be confirmed: Gloria in excelsis Deo, gloria taye'e anumo; Ascenti Deus vetupicopo vitire; Bicofie[s] tarapo viti masachera biya de la Cruz; Boi yoti yurusamurechanu Tata Dios, Taye Jueves Santo, etc. ${ }^{11}$

Centuries later, in the context of the former Jesuit Reductions among Moxo Indians, the name of Jesus Christ was replaced by Viracocha. To our knowledge, it is the first time that in the repertoire of historical music from South America such replacement of names was applied. Viracocha (Wiracocha o Huiracocha) is the name of a supreme deity venerated by Indian communities who populate the Andes of the Bolivian / Peruvian zone - particularly Cuzco and villages around Lake Titicaca. Moxo missions were part of the Peruvian Jesuit Province, and several missionaries who were sent to Moxos spent some time in Cuzco, where they must have learnt about traditional religions, beliefs, rituals, and cults. Is it possible to admit that Jesuit missionaries, in their narrative directed to the local, non-Christian societies with the intent of converting Indians to the Christian faith, explaining the essence of the Incarnated God would compare Him to Viracocha? Or is it a local, post-Jesuit creation, since both the melody and the text display traits of the post-reduction period? Intentionally, we did not choose other names, such as Jesus Christ, Savior, Redeemer etc., but instead chose Emmanuel vs. Viracocha, since it is a Christmas song where this occurs. Thus, the Incarnated God seems to be the most appropriate one. Let us first see the text of the villancico.

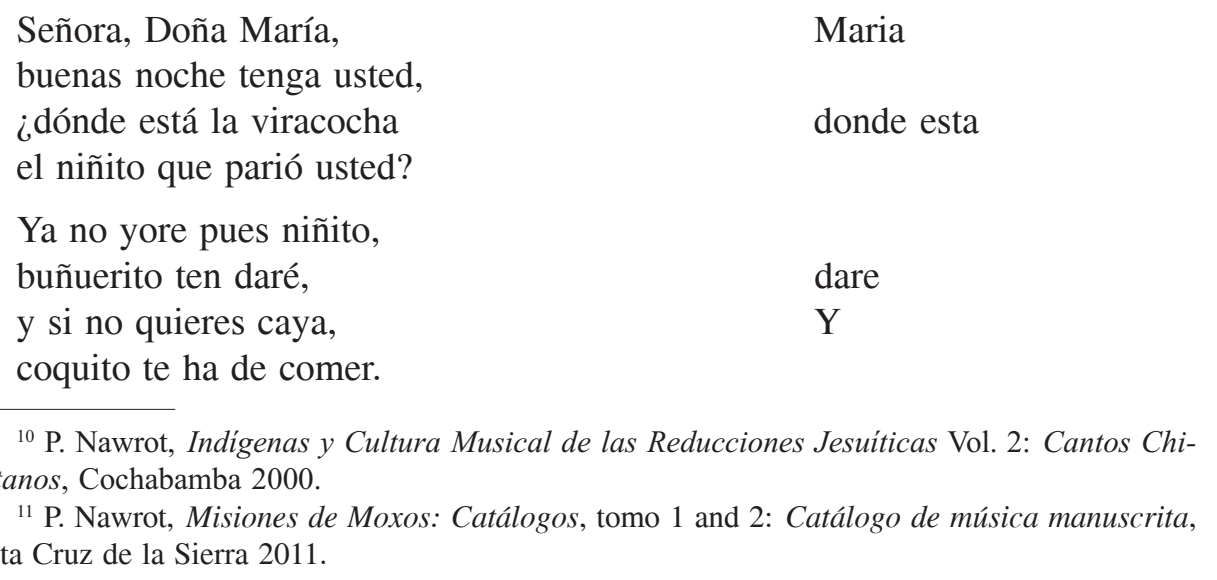
${ }^{11}$ P. Nawrot, Cruz de la Sierra 2011. 

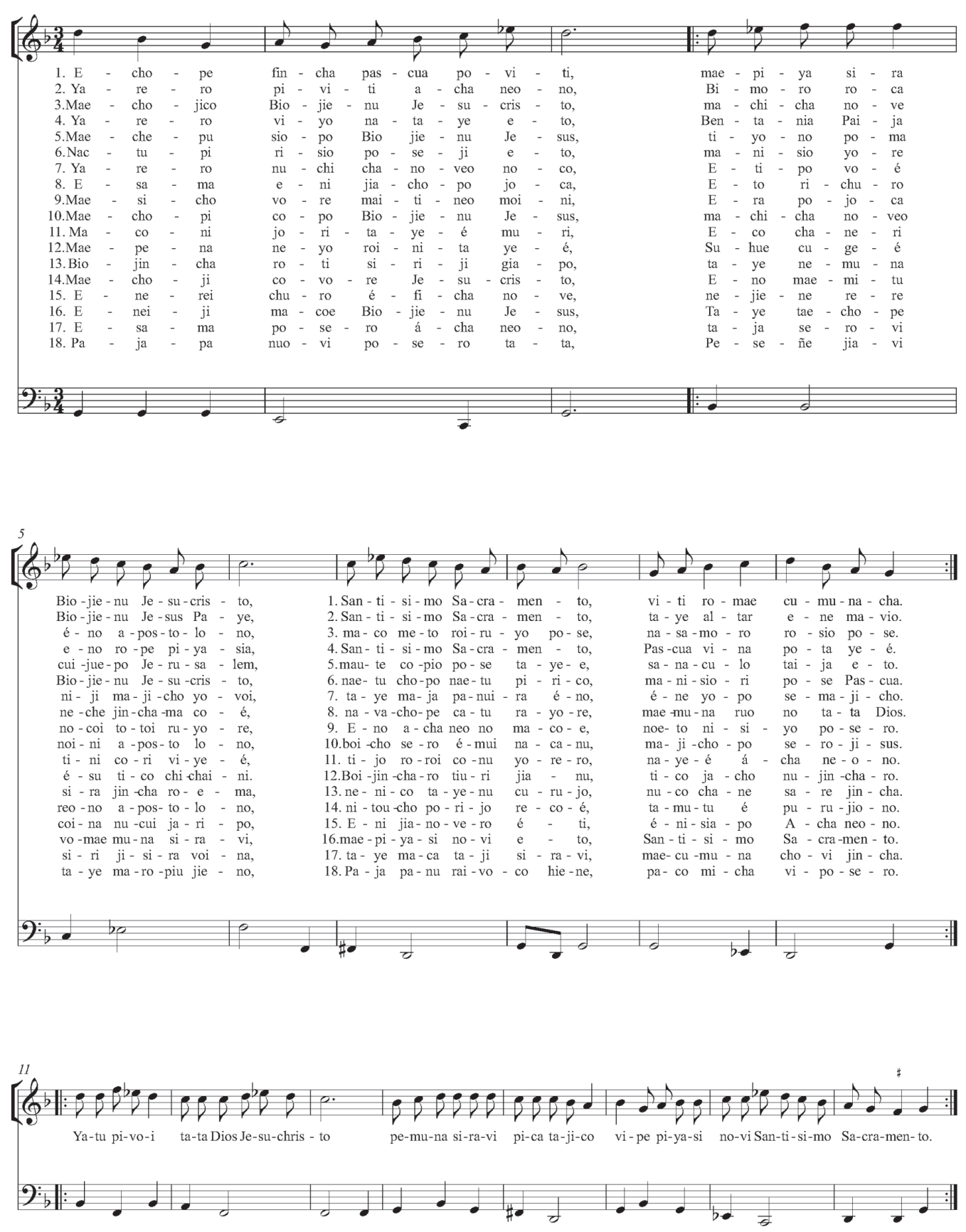

Music example 3: Taye Jueves Santo 


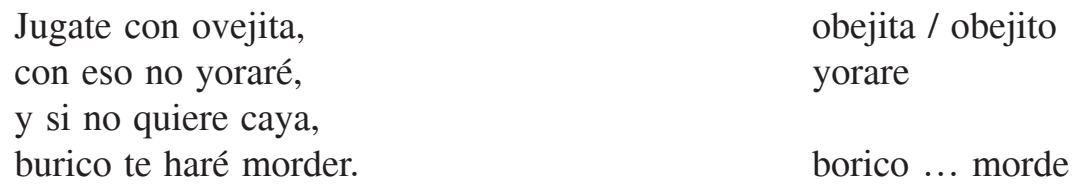

Lady, Doña María, Good Evening [I wish] to you,

Where is the Viracocha, the little boy you gave birth to?

Do not cry, eh, little boy, I will give you buñuerito,

and if you don't stop, I will force you to have coquito.

Play a little with the lamb, with it you won't cry no more,

and if you keep crying, burico will bite you.

It seems that someone simple, one who did not speak Spanish as his/her mother tongue, composed the text. It contrasts very much with lyrics from the time of the Jesuit presence in the missions, which were preoccupied with theological and liturgical content, adequacy, and rightness. The evangelization of Indians was done in local languages and Spanish was imposed upon them decades after the expulsion of the missionaries (1767/1768). It accounts for multiple problems with regard to orthography of the text in Spanish.

There are three copies of the vocal parts in the archives. Two of them correspond to Tiple 1 (MOX_0998 and MOX_1001) and one to Tiple 2 (MOX_1002). MOX_0998 and MOX_1002 were copied by the same copyist who did not leave any information regarding his name, date or place where it was done-common information found in music copied in the Moxo missions. MOX_1001 corresponds to a second facsimile of the Tiple 1 part and was done by Mariano Adrián Yaca Mujivaro on December 29, 1974. However, this music must have been composed much earlier; it could be as early as the very beginning of the $19^{\text {th }}$ century.

Also, the three basic components of music, melody, rhythm, and harmony as seen in Señora, Doña María, are very ingenuous when compared to the glories of the Moxo collection of music, such as polyphonic masses by J.B. Bassani (mission arrangements ${ }^{12}$ ), Gloria en honore, by J.I. Brentner, Victimae paschali laudes (AMMoxos, 844), Ascendit Deus in jubilatione (AMMoxos, 765), both by anonymous composers, or the vast majority of compositions from the Jesuit period of the Moxo reductions. It seems that the composer of this piece was a local musician, possibly a maestro de capilla in one of the local communities where this music came from, of the post-reduction period. ${ }^{13}$ Also, the "air" of the

${ }_{12}$ See: P. Nawrot, Archivo Musical de Moxos. Antología, 4 vols. Vol. 1: Evangelización y Música en las Reducciones de Moxos, chap. 5.

${ }^{13}$ Over 7,200 written documents that were gathered in the archives of San Ignacio de Moxos were recollected from the vast territory in Bolivia called Beni, and came from twenty-four Indian 
piece reminds one of popular tunes heard in Indian villages of the Beni department in Bolivia. Its purpose was not to be sung in formal services, such as Mass or Vespers, but to embellish popular festivities related to Christmas.

The flow of music comes very close to a religious dance related to the Christmas celebration, and is popular in almost every village in Moxos, called el sarao. Even today, this elegant dance is very much present in popular celebrations of Christmas all over Beni. This dance could also be incorporated in celebrations for the feast of the patron saint of a village, but this is less common. The Jesuit missionaries knew this dance, and in allowing its presence in the religious festivities, managed to link it to Christmas convinced that its inclusion in the celebration would foster religious joy and spirit of the dancers (usually 8 women, 8 men and one person holding the saro pole) and the faithful. In conclusion, it is the simplicity of the language and of the music that leads us to believe that this composition is from the post-Jesuit period and is a creation of a local composer.

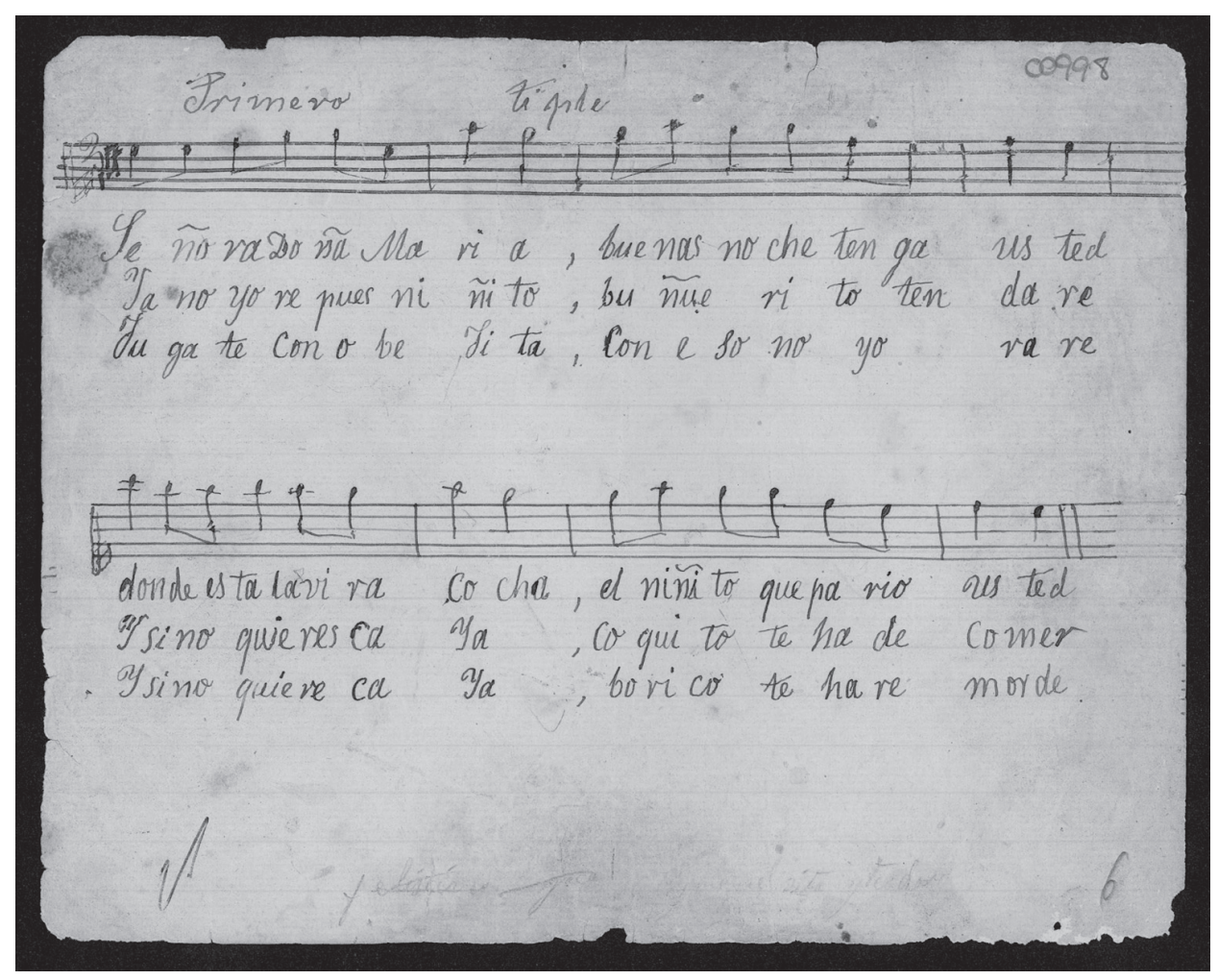

Here is the music itself: MUSIC EXAMPLE NO. 4

communities who copied and used this music for religious services until the present. See: P. Nawrot, Misiones de Moxos... Catálogos ..., op. cit., vol. 1, p. 31. 
The repertoire of Christmas music in the Moxo collection is broad and consists of vocal and instrumental pieces composed mostly before the expulsion of the missionaries. It is complemented by compositions from the post-reduction period. All together in the catalogue of 1,155 entries, 106 refers to music for Christmas. Most of it corresponds to vocal music that comprises such musical forms as Latin masses, hymns, arias, motets, antiphons and pastorela, devotional songs in native languages and in Spanish, and a set of villancicos in Spanish. It is believed that by the beginning of the $19^{\text {th }}$ century, a set of villancicos in Spanish - many of them for Christmas - was brought to Moxos from one of the Spanish cathedrals in Bolivia such as Potosi, Cochabamba, or another nearby urban cathedral.

The fourteen-verse long Christmas song, Natus est hodie (AMMoxos, 921), in the native language of the Moxo - Trinitarian Indians, narrates episodes related to Christ's birth. We use this composition to visualize the attitude of the Indian musicians toward music that was brought to the missions from abroad, in this case, from Spain. Originally set for choir $a$ 4, violin and bc, the villancico, $A l$ portal llegaron (title of the same song, but in Spanish), consists of four sections: (1) instrumental introduction; (2) introductory coplas for choir; (3) dance in $3 \times 8$, first played on instruments, but in the second part, the choir comes in; (4) instrumental introduction to coplas and coplas for soprano solo. Once in the missions, the composition would suffer the following changes: First, the Spanish texts would be replaced by native verse that could be a simple translation, or as it is in this case, written on the same subject, but anew. Then, music would be simplified. In this case, section 1 and 2 were completely omitted. The local maestro de capilla, to whom we ascribe these modifications, would start with coplas, preceded by instrumental introduction. Each copla would be followed by a refrain based on music sung by the four-part choir in the dance (3) section of the original. Here, the response is sung by the choir, but in unison. The instrumental introduction of this dance movement, originally sixteen-bars long, would be reduced to only two bars.

Even though seventeenth and eighteenth-century narratives from the missions attest to the presence of native music in celebrating Christmas in the Jesuit reductions, our knowledge of this repertoire is incomplete. Only since the music from the Moxos territory was gathered in the archives could we debate on this subject with more precision. Up to this point of our studies, we have verified how the Indian culture was looking for its way to be more present in the religious life of local society. Formal prayer, such as Mass and the Liturgy of the Hours - could not be conducted in the local tongue, nor include (unless very hidden in polyphonic harmony) native tunes. However, a celebration of a feast would comprise far more than the formal cultic gathering. Even today, in most of the Indian villages of the Moxo zone in Bolivia, a celebration of a feast is not limited to the 


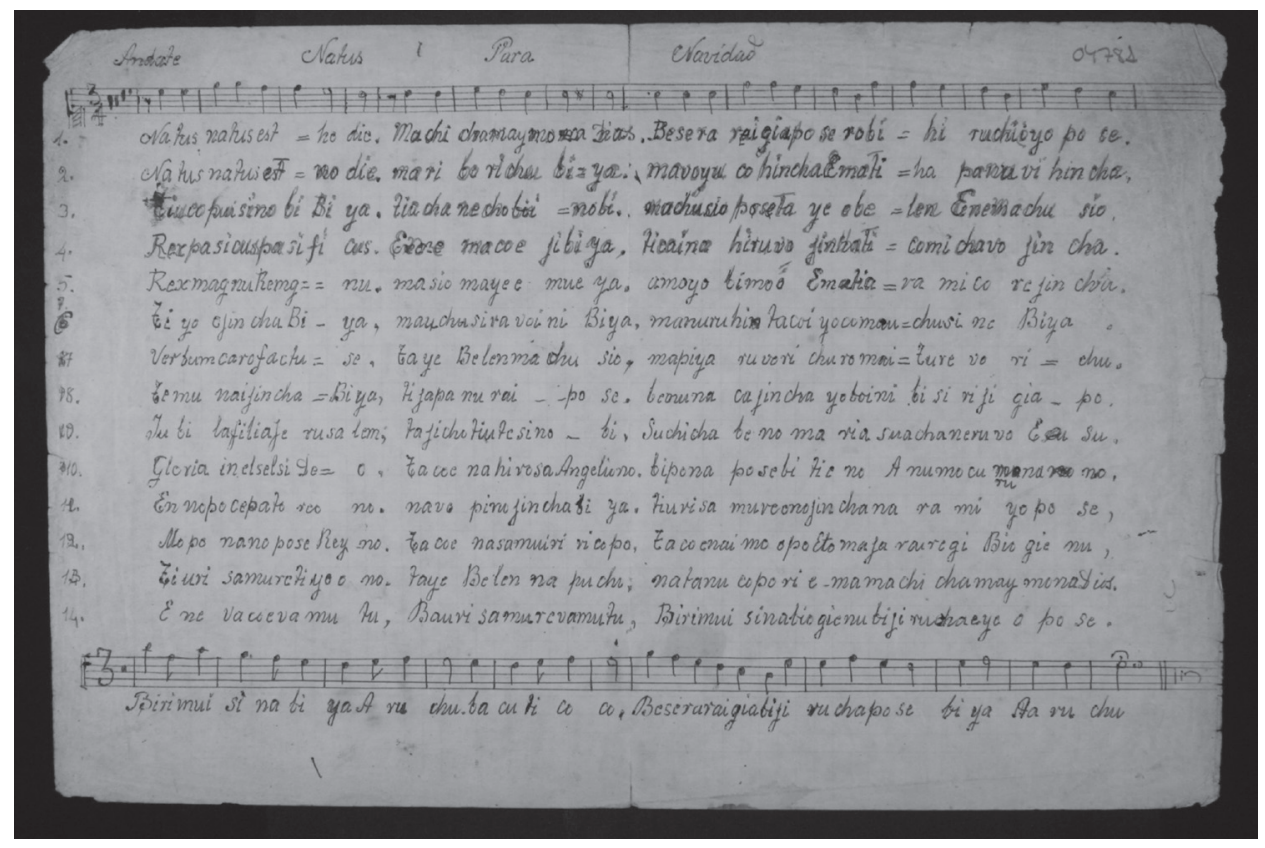

Example 5

Instrumental native music for Christmas: huerure, macheteros

Eucharist $^{14}$, but comprises a whole range of religious and cultural events that mix, complement each other, emanate from one another, or lead to another event. Almost all major feasts in the missions are preceded by a so-called novena - nine consecutive days of preparatory prayers and cultural activities announcing and preparing for the day of the main celebration. Christmas and the feast of the patron saint of the mission are on the top of the list of such feasts. The central point of the celebration is the Holy Mass. But in Indian villages, a Mass does not begin and end with the departure or return of the priest from and to the sacristy. A solemn Mass must include at least two processions. The first one, from Indian houses to the church where Mass will be officiated ${ }^{15}$ and, the second one at the end of the Mass, when, a manner of Corpus Christi, all leave the space and march in the most solemn procession, organized according to the hierarchical structure

${ }^{14}$ As a matter of fact, due to the expulsion of Jesuit priests from the missions and only sporadic visits (once or twice a year) of their successors, the local communities took the matter of religious life of the society into their hands. After two hundred and fifty years without regular mass, today, while visiting some of these villages, one might get the impression that mass is no longer seen as the indispensable component of the celebration of the feast. It is still eagerly desired, but not perceived anymore as constitutional, without which the celebration must be suspended.

${ }^{15}$ Such procession would not be called for when people gather for other religious or cultural activities. 
of the Indian community, around the plaza. When cacique - still very much respected and in office in most of the mission villages - or other major authorities leave their houses to attend mass, they will be accompanied by a group of musicians playing a native jerure (herure), while after the Mass, all will walk around the plaza to the sound and dance of macheteros. What must be noticed here is the fact that not only do these two compositions have native melodies, but also they are played on native instruments. Already during the foundation times, but also today, the spectacle is remarkable, and awakens in locals and visitors the most profound admiration and approval.

Local composers would differentiate the musical nature of a jerure or macheteros according to the character of the celebrated feast. Some will be felt as more joyous, some others as more solemn and mysterious. With accordance to the hierarchy of a feast, some of them would have several melodies composed for the day and the local musicians would use it according to their will and disposition. It is common in Moxos that feasts of lesser rank would have only one jerure melody for the feast. The machetors dance would be borrowed from another festivity.

Atomization in celebrating feasts in the missions, in the historic times or today, does not do justice to what religious life of Indian communities was and is today, and can be misleading in interpretation of this phenomena. Indian and European, traditional and new, autochthonous and foreign, all of these and more gave birth to something new, which is not purely Indian (anymore) or European (anymore), but properly reduccional, or missional. Having this in mind, let us demonstrate the main components of the central part of the celebration of Christmas in the missions: the Eucharist.

The celebration would start with bringing people to church to the sound of flutes (Indian in origin), sometimes together with violins (adopted in the missions) and local percussion instruments (tambor y/or bombo) resounding autochthonous jerure. In general, the melody instruments play in unison, or a third or sixth apart. The catalogue of the Moxo collection of music lists 16 instrumental compositions for Christmas; twelve of them were classified as jerure (sometimes: Herure de Pascua de Navidad). Even though this number seems to be rather sizeable, it should not be understood to be the whole repertoire of Christmas jerures in Moxo. It is representative of what was recorded in musical notation by local musicians and included in the Moxo collection. It is difficult to speculate how many more of these compositions are still in use in the Moxo villages, but it could be asserted that many more are being used today even though were note codified in music scores. What is included here is still applied for Christmas celebration in some villages in Moxos.

There are forty-two polyphonic masses in the Moxo collection. Two of them, Misa Romana (AMMoxos, 748) and Misa Feria (AMMoxos, 741) contain one 

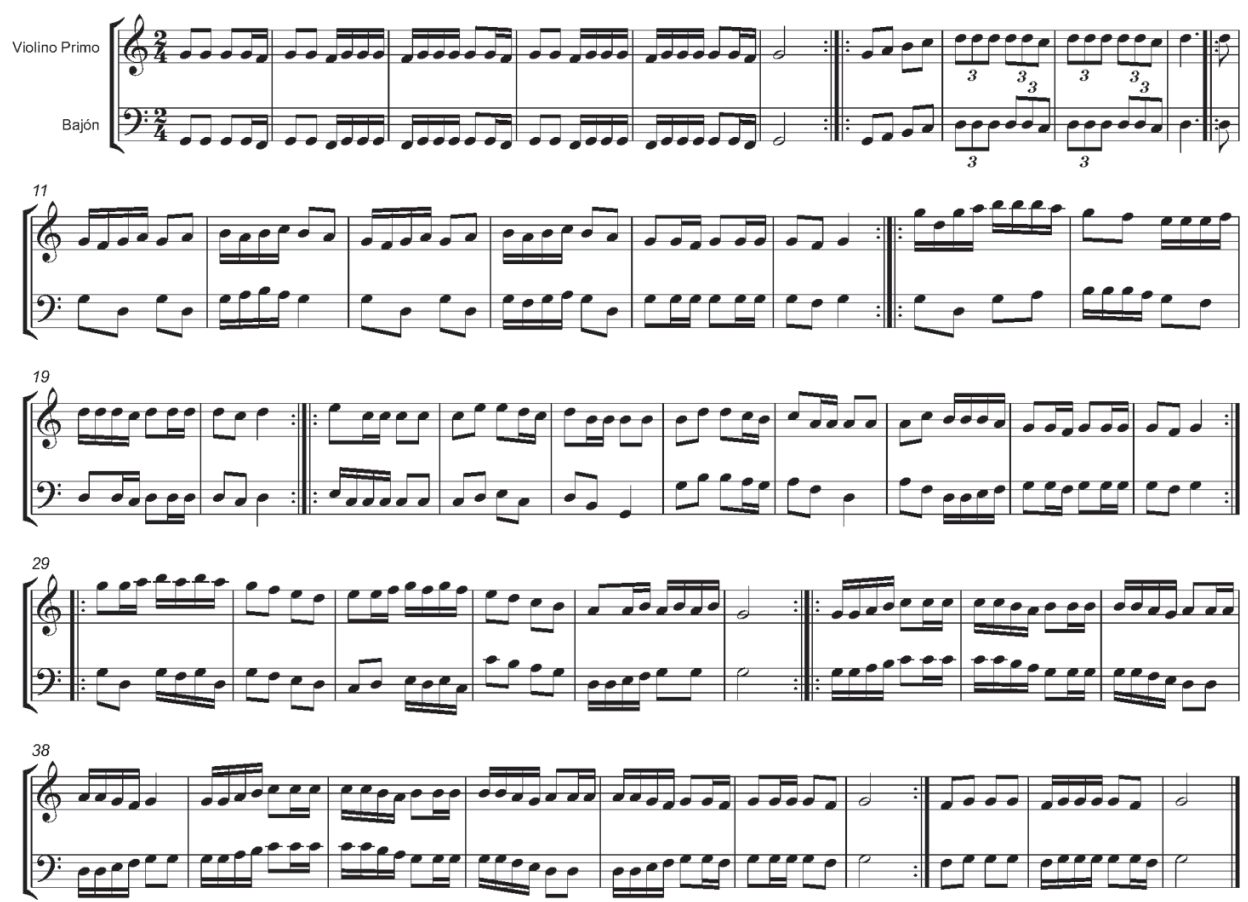

Music example 6

or more parts that include an indication that they were destined to be sung for Christmas celebrations. Both of them are of European origin, but in the mission, were passed through a process of accommodations. The second one of the two, Misa Feria, was also found in another collection of music from the former Jesuit reductions - Chiquito missions - where it is called Missa a la Fuga de San Joseph. The "Indian" ingredient in Latin mass can only be seen when the original, Acroama missale "Missa III" by Giovanni Battista Bassani, is compared with the mission version (Misa Feria) modified by local musicians. It was already demonstrated in a recent publication of this mass reconstructed on documentation from the Chiquito archives that it seems to be the same as found in Moxos. ${ }^{16}$ The formal Latin mass of the time would sanction use of local languages or autochthonous instruments, and this would also be restricted in Europe or on other continents. The liturgical law of the time was quite restrictive in this regard, even when it was implemented in the mission territories.

${ }^{16}$ See: Missa a la Fuga de San Joseph, ed. P. Nawrot, Santa Cruz 2008. 


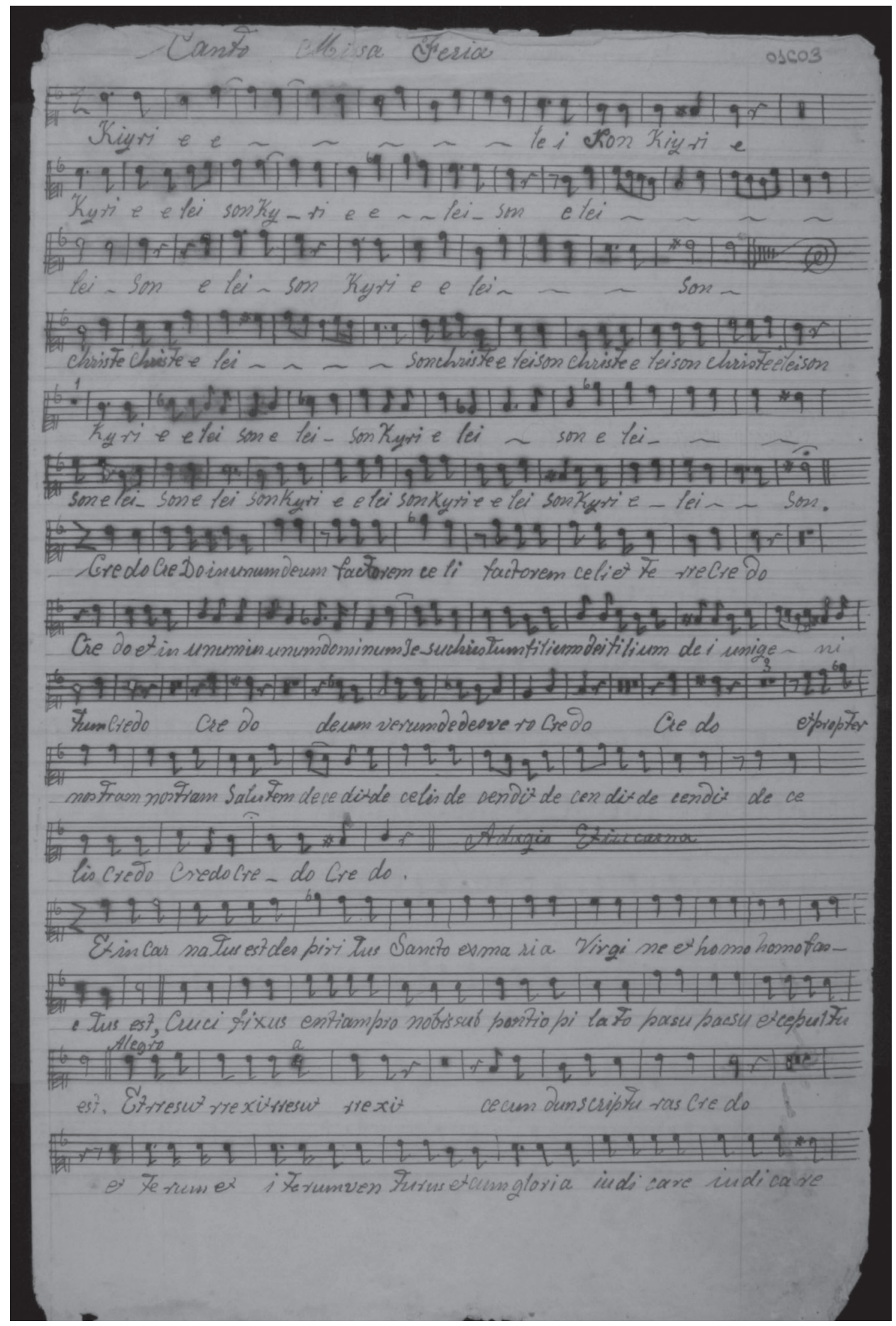

Music example 7 
At the end of the mass, but without any separation between the mass and the procession that follows, a splendid choir of macheteros, implacably dressed in the most decorative traditional way, would wait at the very entrance of the church to start the procession around the plaza or even larger space that might include a few of the streets adjacent to the plaza. Usually, macheteros do not enter the space where the Eucharist is celebrated; although today, there are villages where the procession might start from the altar and not from the entrance. Everywhere and every time when macheteros participate in the celebration, they dance to the sound of native music performed on autochthonous instruments: flutes, pífanos, sancutis, cajas and bombos. ${ }^{17}$ All consider this as the most festive moment of the celebration.

Until recently, the melodies of music that accompany this dance were transmitted orally. However, in the Moxo collection, there is one example of music for this dance that was codified in musical notation. The composition in not recent and could have originated in the Jesuit period of the history of the Moxo villages. There are three copies of the music. What is striking is the instrumentation of this piece that includes violins, and which is repeated both times. The older copy, done by one of the most important copyists of the early period, Pascual Conotire Napicororu Guaji, was dated December $28^{\text {th }}, 1895$. What is remaining in the collection is the violin part, which says: Violino Primo $1^{\circ}$ Unisono Machetero. Inclusion of the word unisono might be interpreted that this music was played by more than one violin. But, most probably, it says that the violin was playing in unison with flutes, perhaps pífano and other native instruments. ${ }^{18}$ The same is confirmed in the copies made by the greatest of all copyists that ever lived in Moxos, Manuel Jesús Espíritu Mahe Noco Guaji. ${ }^{19}$ Manuel Espíritu Mahe, as often his name was noted on the facsimiles, copied this music on December $24^{\text {th }}, 1908$. He left us both violin and bass parts. On the sheet corresponding to violin part it says: Violino Primo Unizono para Machetero Navidad, while the bass part states: Bajon para Machetero de Navidad. There is beyond any doubt that, for the Indian musicians and society, the separation between autochthons and foreign, at least in the field of religious activities, was never practiced or stood in opposition in one anther.

${ }^{17}$ Cajas and bombos are used to accompany this dance all over Moxos. However, flutes, pifanos, sancutis, or still other native instruments that play the melody could vary from village to village.

${ }^{18}$ In my visits to Moxos between 1991 and 2015, I do not remember that I have seen such combination of instruments. Perhaps this is because around the 1960s, violins were almost abandoned for the lack of strings in the small villages of Moxos.

${ }^{19}$ Misiones de Moxos: Catálogos, ed. P. Nawrot, vol. II : Catálogo de copistas de música manuscrita / Ana Luisa Arce, Santa Cruz 2011, pp. 405. 

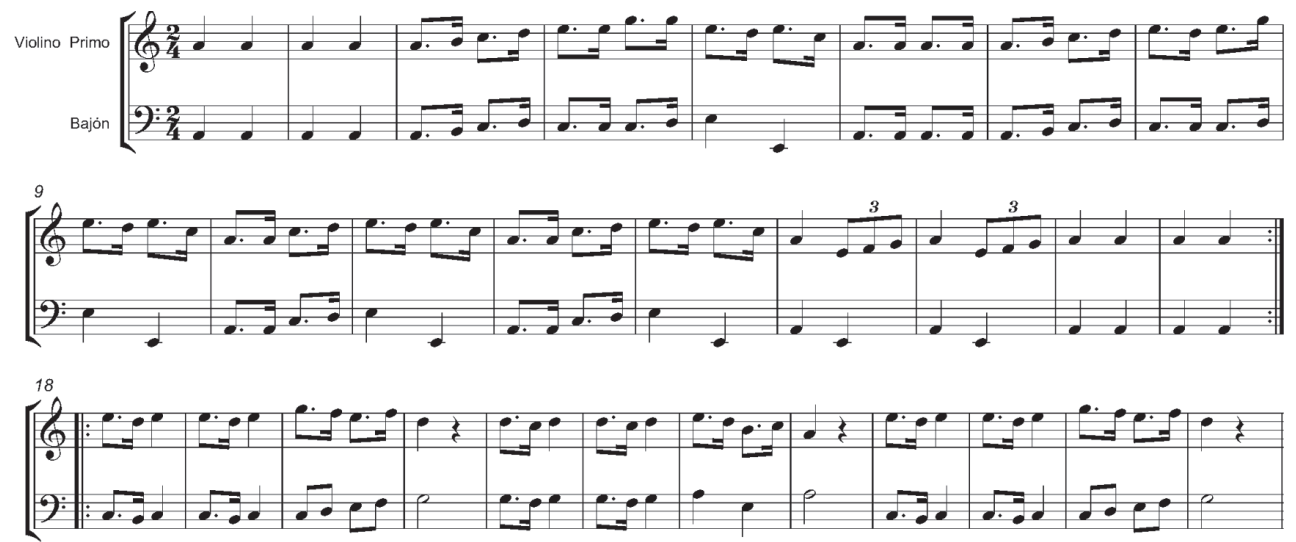

Let us see this unique, on world scale, example. Ex. 8

Christmas celebrations in small Indian villages should not be reduced to formal liturgical services, such as mass and vespers. If so, the influence of the Indian culture on the event could be perceived with its ampler manifestation. There are a number of dances associated with Christmas that, in successive exhibitions, narrate episodes about the manger and adoration from the context of the Moxo villages. Heavenly creatures - los angelitos, historic societies - los herodes, together with the locals - las barbaras, los graciosos, los macheteritos, el saro y el barco, all meet around the newly-born Jesus to the sound of varied local melodies played on autochthonous and "new" instruments, and dance for Him a distinctive, for the group that is present, dance.

Christmas celebrations in Indian villages in Bolivia were and are celebrated with great solemnity. A broad repertoire of music was created through the century that is apt to solemnize almost every moment of Christmas: solemn mass, vespers, processions, dances or popular gatherings. Indian influence on this repertoire could be seen in several moments: use of local languages, inclusion of autochthonous dances and instruments, mix of European and Native American traditions. This led to a creation of something new, that was not any more purely European neither merely native. It represents new creation, proper to milieu of its origin, the mission, called also reduction where the Indian taste for music, harmony and rhythm, Indian spirituality and mentality could be attested in several moments.

\section{Abstract}

The subject of Indian music and Indian influence on baroque music from the former Jesuit Reductions in South America needs new studies, and what has been said on this matter up to now by musicologists and ethnomusicologists needs revision. The finding of almost 13,000 pages of 
baroque music from the Chiquito and Moxo Reductions in Bolivia gives us new opportunity to clarify Native American's attitude toward music introduced in the missions by the missionaries and to illustrate their influence on music created or written anew in the missions by the missionaries and local musicians. In the context of music for Christmas celebration a serious of arguments are discussed to clarify the presence of "Indian" components in the baroque music from America, as well as coexistence of autochthonous and "new music" in the missions.

\title{
Keywords
}

Chiquitos, Moxos, La Plata, Jesuit Reductions, Bolivia

\begin{abstract}
Abstrakt
Temat muzyki Indian i wpływu Indian na muzykę barokową z dawnych redukcji jezuickich w Ameryce Południowej potrzebuje nowych badań, a to, co zostało powiedziane w tej sprawie do tej pory przez muzykologów i etnomuzykologów wymaga rewizji. Odkrycie prawie 13.000 stron muzyki barokowej z jezuickich redukcji Indian Chiquito i Moxo w Boliwii daje nam nową możliwość wyjaśnienia zachowania Indian w stosunku do muzyki wprowadzonej w misjach przez jezuickich misjonarzy, jak również szanse na ilustruje wpływ Indian na muzykę komponowaną, lub na nowo aranżowaną w misjach przez misjonarzy i lokalnych muzyków. W kontekście muzyki na Boże Narodzenie łańcuch argumentów został przedstawiony w celu wyjaśnienia obecności „indyjskich” elementów w muzyce barokowej z Ameryki, a także współistnienie autochtonicznej i „,nowej muzyki" w misjach.
\end{abstract}

\section{Słowa kluczowe}

Chiquitos, Moxos, La Plata, redukcje jezuickie, Boliwia

\section{Bibliography}

Claro V.S., Antología de la Música Colonial en América del Sur, Santiago de Chile: Ediciones de la Universidad de Chile, 1974.

Claro V.S. La Música en las Misiones Jesuitas de Moxos, "Revista Musical Chilena" 23 (1969), pp. 7-32.

Eder F.J., Breve descripción de las reducciones de Mojos, tr. and ed. J.M. Barnadas, Cochabamba: Historia Boliviana, 1985.

McNaspy C.S.I., Art in Jesuit life, "Studies in the Spirituality of Jesuits" 5(1973), pp. 92-111.

Misiones de Moxos: Catálogos, vol. II: Catálogo de misioneros de Moxos (1668-1768) / / Javier Matienzo; Archivo musical de Moxos. Catálogo de copistas de música manuscrita / Ana Luisa Arce; Archivo musical de Moxos. Catálogo inicial de cuadernos doctrinarios / Víctor Rondón; Las misiones de Moxos: Catálogos. Las misiones de Moxos (1767-1842). Algunos datos sobre educación, arte y música / Roberto Tomichá Charupá, ed. P. Nawrot, Santa Cruz: Fondo Editorial APAC, 2011, p. 405.

Missa a la Fuga de San Joseph, ed. P. Nawrot, Santa Cruz: Fondo Editorial APAC, 2008. Nawrot P., Archivo Musical de Moxos. Antología, 4 vols. Vol. 1: Evangelización y Música en las Reducciones de Moxos, vol. 2: Motetes e Himnos. Villancicos. Negrillas. Músi- 
ca Instrumental, vol. 3: Pasión. Salmos. Letanía, vol. 4: Misas, Cochabamba, Editorial Verbo Divino, 2004.

Nawrot P., Czy muzyka może być dzisiaj narzędziem ewangelizacji? Aktualność doświadczeń baroku misyjnego Ameryki Hiszpańskiej, „Teologia Praktyczna”, t. 13(2012), s. 71-82.

Nawrot P., Indígenas y Cultura Musical de las Reducciones Jesuíticas, vol. 1: Guaraníes, Chiquitos, Moxos, vol. 2: Cantos Chiquitanos, vol. 3: Opera San Francisco Xavier, vol. 4: Réquiem Chiquitano, vol. 5, Cantos Guaraníes y Moxeños, Cochabamba: Editorial Verbo Divino, 2000.

Nawrot P., Misiones de Moxos: Catálogos. Archivo musical de Moxos. Catálogo de música manuscrita. Vol. I. - Book I, Fondo Editorial APAC. Santa Cruz. Bolivia 2011, pp. 1-592.

Nawrot P., Misiones de Moxos: Catálogos. Archivo musical de Moxos. Catálogo de música manuscrita. Vol. I. - Book II, Fondo Editorial APAC, Santa Cruz. Bolivia 2011, s. 593-1270.

Nawrot P., The Jesuit Reductions. Infusion of the Indian Element into Musical Practice, „Studia Missionalia” vol. 62(2013), s. 141-162.

San Ignacio. Ópera de las misiones jesuíticas, Archivo Musical de Chiquitos. Archivo Musical de Moxos. [+ Violín 1, Violín 2, Órgano, Trompa], ed. P. Nawrot, Fondo Editorial APAC, Santa Cruz de la Sierra, Bolivia 2012, ss. $130[+23+23+25+3]$.

Stevenson R., Latin American Colonial Music Anthology, Washington, D.C.: Organization of American States, 1975.

Stevenson R., Music in Aztec and Inca Territory, Berkeley-Los Angeles: University of California Press, 1968.

Stevenson R., The Music of Peru, Washington, D.C.: Pan American Union, 1960. 